\title{
Haemorrhagic smolt syndrome (HSS) in Norway: pathology and associated virus-like particles
}

\author{
A. Nylund ${ }^{1, *}$, H. Plarre ${ }^{1}$, K. Hodneland ${ }^{1}$, M. Devold ${ }^{1}$, V. Aspehaug ${ }^{1}$, M. Aarseth ${ }^{1}$, \\ C. Koren ${ }^{1,2}$, K. Watanabe ${ }^{1}$ \\ ${ }^{1}$ Department of Fisheries and Marine Biology, University of Bergen, 5020 Bergen, Norway \\ ${ }^{2}$ Present address: Fiskehelse Nord AS, 9485 Harstad, Norway
}

\begin{abstract}
Atlantic salmon Salmo salar pre-smolt, smolt and post-smolt, with clinical signs of haemorrhagic smolt syndrome (HSS) have been found in several locations along the Norwegian coast (Rogaland to Troms). Affected fish had pale gills and bleeding at the fin bases, but seemed to be in good physical condition with no obvious weight loss. The internal organs and body cavity showed distinct bleedings. Petechiae were found on the gastrointestinal tract, swim bladder and peritoneum, visceral adipose tissue, heart and somatic musculature. The liver was bright yellow and sometimes mottled with petechiae and ecchymoses. Acitic fluid was found in the visceral cavity and fluid was also present in the pericardial cavity. Histological examination revealed haemorrhage in most organs. The glomeruli were degenerated and the renal tubules were filled with erythrocytes. The aims of this study were to describe the pathology and discover, if possible, the aetiology of the HSS. Tissues were collected for light and transmission electron microscopy (TEM), immunofluorescence (IFAT), reverse transcription (RT)-PCR diagnostics (screening for infectious salmon anaemia virus [ISAV], viral haemorrhagic septicaemia virus [VHSV], salmon pancreas disease virus [SPDV], sleeping disease virus [SDV] and infectious haematopoetic necrosis virus [IHNV]), and tissue homogenates (heart, liver, kidney and spleen) were sterile-filtered and inoculated into cell cultures. Homogenates made from several tissues were also injected intraperitoneally into salmon and rainbow trout Oncorhynchus mykiss. The diagnostic tests revealed no consistent findings of any pathogens, with the exception of TEM which showed 2 types of virus-like particles: Type I was 50 to $60 \mathrm{~nm}$ in diameter and Type II about $50 \mathrm{~nm}$ in diameter. These virus-like particles were found in salmon from all farms affected by HSS and screened by TEM. Several different cells, blood vessel endothelial cells, endocardial cells, heart myofibres, and leukocytes were associated with the 2 viruslike particles. The Type I particle seems to be an infectious pancreatic necrosis (IPN)-like virus, while (based on the number of target cells, particle morphology, budding and uptake into target cells) Type II particle could be a togavirus.
\end{abstract}

KEY WORDS: Haemorrhagic smolt syndrome $\cdot$ Pathology · Virus Resale or republication not permitted without written consent of the publisher

\section{INTRODUCTION}

Haemorrhagic smolt syndrome (HSS) or haemorrhagic diatesis ('blødersyndrom') is a disease condition of salmon Salmo salar that induces dramatic pathological changes. The disease occurs on pre-smolt, smolt and post-smolt, and has been an annual problem in Norwegian smolt production from Rogaland to Troms. The disease has also been recorded (February 1996) in western Scotland, where it was described for pre-smolt

*Email: are.nylund@ifm.uib.no from a stock with low-level mortalities by Rodger \& Richards (1998), who termed the disease haemorrhagic smolt syndrome (HSS). The key characteristics were described as widespread visceral petechiation and ecchymoses, low haematocrit values, and widespread haemorrhage in all organs associated with endothelial tissue. Infectious agents were not found and the condition was considered non-infectious. Smolt with HSS from Norwegian salmon farms show, to a large extent, the same clinical signs as those described by Rodger \& 
Richards (1998). Mortality is usually low, and usually $<0.5 \%$.

Based on clinical signs, this disease has been confused, to some degree, with other haemorrhagic diseases in Norwegian aquaculture (e.g. infectious salmon anaemia), and the dramatic internal changes (haemorrhage and discolouration of the internal organs) always alarm salmon farmers and veterinarians. Although mortality associated with the disease is fairly low, when this disease is observed at a farm, every precaution should be taken to prevent its spread, since its aetiology is unknown and an infectious nature cannot be excluded.

Although no infectious agent has been isolated from fishes with HSS, the disease shows great similarities with some viral infections (cf. Wolf 1988). The aims of the present study were to describe the clinical signs of the disease and pathological changes of affected salmon in Norway, to screen affected smolt for several of the known viruses that occur in the production of salmon to see if any of these are associated with the disease, and to screen for possible 'new' viral agents with the help of cell cultures and transmission electron microscopy.

\section{MATERIALS AND METHODS}

Atlantic salmon Salmo salar smolt (150 to $200 \mathrm{~g}$ ) diagnosed as suffering from HSS or haemorrhagic diateses ('blødersyndrom'), were collected from 4 farms on the west coast of Norway in 1999 (Table 1): Hordaland (a few pieces of kidney tissue supplied by Intervet Norbio), Rogaland (whole live fish supplied by A. Litlabø), Sogn og Fjordane (selected tissues supplied by C. Myklebust), and Møre og Romsdal (selected tissues supplied by A. Lyngøy). All samples were taken from the fish before these were transferred to full-strength sea water. In addition, heart and kidney tissues from a farm in northern Norway (Troms) were collected and prepared for transmission electron microscopy (TEM) only (Table 1). The fish were diagnosed by the local National Veterinary Service. The proportion of the fish that died in tanks varied from 0.29 to $0.63 \%$, while total mortality in affected farms never reached more than $0.24 \%$.

Tissues (kidney, heart, liver, spleen, somatic muscle, gills, pancreas, visceral fat and gut) were collected and fixed (Karnovsky fixative) immediately, or frozen in liquid nitrogen and stored at $-80^{\circ} \mathrm{C}$. The fixed tissues were embedded in Epon 812 and historesin and sectioned for transmission electron and light microscopy (cf. Nylund et al. 1995). Tissues from 3 farms were examined by TEM; Rogaland (4 March and 16 April), Sogn og Fjordane, and Troms.

Kidney, liver, spleen and heart tissues were homogenised, filtered $(0.2 \mu \mathrm{m})$, diluted 1:100 with phosphatebuffered saline (PBS), and incubated for $3 \mathrm{~h}$ at $15^{\circ} \mathrm{C}$ in cell culture flasks with a monolayer of ASK-cells, chinook salmon embryo (CHSE)-214 or epithellma papillosom cyprini (EPC) (Table 1). Since smolt at one of the farms had infectious pancreatic necrosis virus (IPNV) (diagnosed by the local National Veterinary Service), and smolt of the other farms were suspected to be IPNVpositive neutralisation (polyclonal antiserum, $\varnothing 456$ against the SP strain of the IPNV: Frost et al. 1998) was carried out before inoculation. (All farms had a history of IPNV.) The inoculum was then removed and replaced by L-15 medium (BioWittaker) supplemented with foetal calf serum (FCS) $(2 \% \mathrm{v} / \mathrm{v})$, gentamicin $\left(50 \mu \mathrm{g} \mathrm{m}^{-1}\right)$ and L-glutamine $(4 \mathrm{mM})$. The cells were kept at $15^{\circ} \mathrm{C}$ for $12 \mathrm{~d}$ or until a cytopathic effect (CPE) could be observed. The culture medium of cells considered negative after $12 \mathrm{~d}$ was used as an inoculum for passage through new cells. The samples were passed 3 times before they were considered negative. A negative control cell culture was always included.

RNA extracted from frozen tissues (kidney, liver, spleen, heart, pancreas, and gill) was used for RT-PCR

Table 1. Diagnostic methods used for screening tissues with haemorrhagic smolt syndrome $(\mathrm{K}=\mathrm{kidney}, \mathrm{L}=$ liver, $\mathrm{H}=\mathrm{heart}$, $\mathrm{G}=$ gills, $\mathrm{M}=$ somatic muscle, $\mathrm{P}=$ pancreatic tissue/visceral fat, $\mathrm{D}=$ gut, $\mathrm{S}=$ spleen). IFAT: immunofluorescence; RT-PCR: reverse-transcription PCR; TEM: transmission electron microscopy

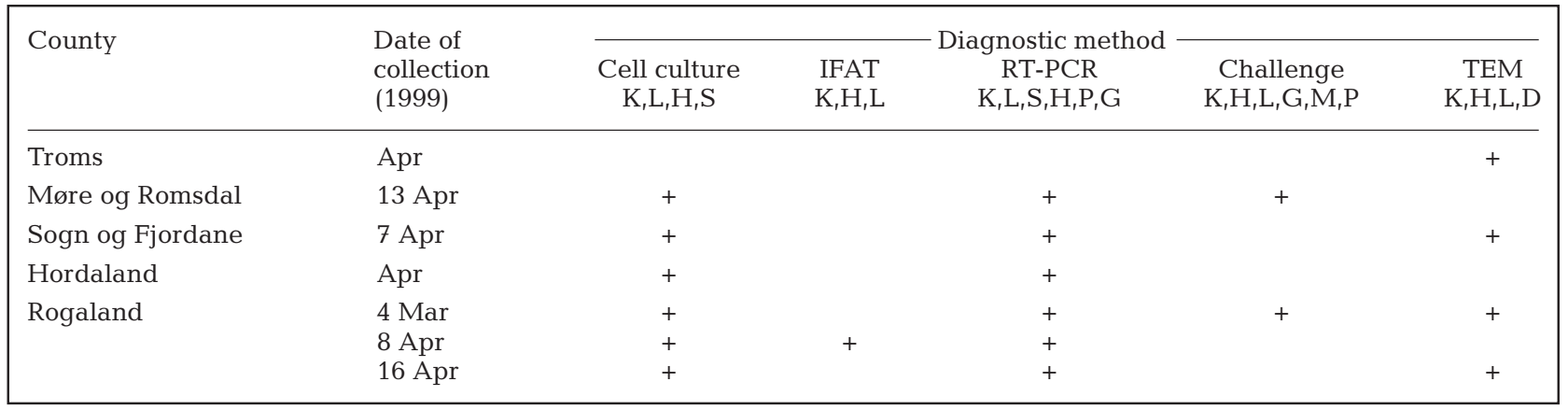


(cf. Devold et al. 2000). The fish were screened for infectious haematopoietic necrosis virus (IHNV) (Miller et al. 1998), viral haemorrhagic septicaemia virus (VHSV) (Miller et al. 1998), infectious salmon anaemia virus (ISAV) (Devold et al. 2000), sleeping disease virus (SDV) and salmon pancreas disease virus (SPDV). The primer sets used for RT-PCR are given in Table 2.

Tissue homogenates from 2 of the farms were also used to challenge Atlantic salmon Salmo salar $(\mathrm{N}=30)$ and rainbow trout Oncorhynchus mykiss $(\mathrm{N}=30)$ in running sea water (34\%) (Table 1). The fish were given an intraperitoneal injection of $0.2 \mathrm{ml}$ of the homogenate diluted 1:1 with PBS. Injected fish were kept in separate tanks at $12^{\circ} \mathrm{C}$. The mean weight of the salmon and trout were 31 and $65 \mathrm{~g}$, respectively.

Heart, liver and kidney collected from 3 moribund fish (Rogaland, 8 April) with clinical signs of HSS were examined for ISAV and IPNV by immunofluorescence (Table 1). Frozen tissue from individual fish were embedded in mounting medium and cut on a cryostat, picked up on poly-L-lysine-coated slides and fixed in chilled $100 \%$ acetone for $10 \mathrm{~min}$. After blocking in 5\% skimmed dry milk for $30 \mathrm{~min}$, sections were incubated with primary antibody overnight. One monoclonal antibody (Clone 3H6F8) and 1 polyclonal antibody (K-149) against ISAV, and 1 monoclonal antibody against IPNV (all described in Szilvay 1988 and Falk \& Dannevig 1995) were used, diluted 1:250, 1:500 and 1:100 respectively in $2 \%$ skimmed dried milk in PBS. Antibody K-149 was absorbed onto Atlantic salmon head kidney cells (SHK-1) prior to use. Bound antibodies were detected by fluorescein isothiocyanate (FITC)-conjugated goat antisera against mouse im- munoglobin (Ig) (Southern) or against rabbit IgG (Southern). Sections were finally mounted using a SlowFade ${ }^{\mathrm{TM}}$ Antifade Kit (Molecular Probes), following the manufacturer's instructions. All steps, except blocking, were followed by washing in PBS ( $\mathrm{pH} 7.4$ ) containing $0.1 \%$ Tween-20 for at least 5 min, changing the buffer 3 times. Positive controls were included.

All fish were examined for parasites and the presence of bacteria. Scrapings from skin, fins and gills were examined in a light microscope at 3 different magnifications $(\times 100, \times 400$ and $\times 1000)$. The digestive tract was screened for helminths and tissues from the various organs were examined in squeeze preparations and on semithin sections (light microscope) and ultrathin sections (TEM). Bacteriological examination consisted of inoculation of kidney tissue onto blood agar plates incubated at $20^{\circ} \mathrm{C}$ for $7 \mathrm{~d}$ and onto blood agar plates containing $2 \% \mathrm{NaCl}$ incubated for $7 \mathrm{~d}$ at $15^{\circ} \mathrm{C}$.

\section{RESULTS}

Mortality of Salmo salar smolt in the farms where the fish were collected was low $(<0.5 \%)$, and the fish seemed to recover and mortalities ceased after transfer to the sea (reports from the local National Veterinary Service). There were no reports of recurrence of the problem after transfer to the sea. Salmon from all farms showed the same clinical signs of disease. Most fish were in excellent condition, showing normal behaviour, but some were lethargic and some even failed to maintain a horizontal position. Moribund specimens

Table 2. Primer sets used to diagnose haematopoetic necrosis virus (IHNV), viral haemorrhagic septicaema virus (VHSV), infectous salmon anaemia virus (ISAV), salmon pancreas disease virus (SPDV) and sleeping disease virus (SDV) in Salmo salar. Primers against the MHC-I were used as a positive control for reverse transcription (RT). The PDF1/PDR1 primer set was designed against a conservative region found in an alignment between an SPDV sequence (AJ012631) and an SDV sequence (AJ238578)

\begin{tabular}{|c|c|c|c|}
\hline Virus & Primer set & Name & Source \\
\hline IHNV & $\begin{array}{l}5^{\prime} \text {-ATG ATC ACC ACT CCG CTC ATT-3' } \\
5^{\prime} \text {-CTC TGG ACA AGC TCT CCA AGG-3' } \\
5^{\prime} \text {-GAT TGG AGA TTT TAT CAA CA-3' }\end{array}$ & $\begin{array}{l}\text { IG1 } \\
\text { ID4 } \\
\text { ID3 }\end{array}$ & Miller et al. (1998) \\
\hline VHSV & $\begin{array}{l}\text { 5'-ATG GAA TGG AAC ACT TTT TTC-3' } \\
5^{\prime} \text {-TCC CGC TAT CAG TCA CCA G-3' } \\
5^{\prime} \text {-TGT GAT CAT GGG TCC TGG TG-3' }\end{array}$ & $\begin{array}{l}\text { VG1 } \\
\text { VD5 } \\
\text { VD3 }\end{array}$ & Miller et al. (1998) \\
\hline ISAV & $\begin{array}{l}\text { 5'-GAA GAG TCA GGA TGC CAA GAC G-3' } \\
5^{\prime} \text {-GAA GTC GAT GAA CTG CAG CGA-3' }\end{array}$ & $\begin{array}{l}\text { FA-3 } \\
\text { RA-3 }\end{array}$ & Devold et al. (2000) \\
\hline SPDV & $\begin{array}{l}5^{\prime} \text {-CGA CTA CTC CCC ATT CGA TCG-3' } \\
5^{\prime} \text {-GCT CCT AGT GAG CAA TTT GTA TAC CG-3' }\end{array}$ & $\begin{array}{l}\text { F2 } \\
\text { R5 }\end{array}$ & K. Hodneland (unpubl.) \\
\hline SPDV/SDV & $\begin{array}{l}5^{`}-\mathrm{CTG} \text { CCG CCG TTT ACG ACA CAC-3' } \\
5^{\prime}-\text { CAC CTT ACC GTC CCT TCC CAG-3' }\end{array}$ & $\begin{array}{l}\text { PDF1 } \\
\text { PDR1 }\end{array}$ & \\
\hline MHC-I & 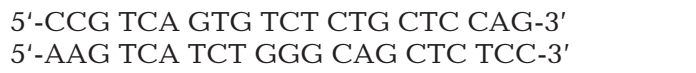 & $\begin{array}{l}\text { MHC-IA } \\
\text { MHC-IB }\end{array}$ & Devold et al. (2000) \\
\hline
\end{tabular}




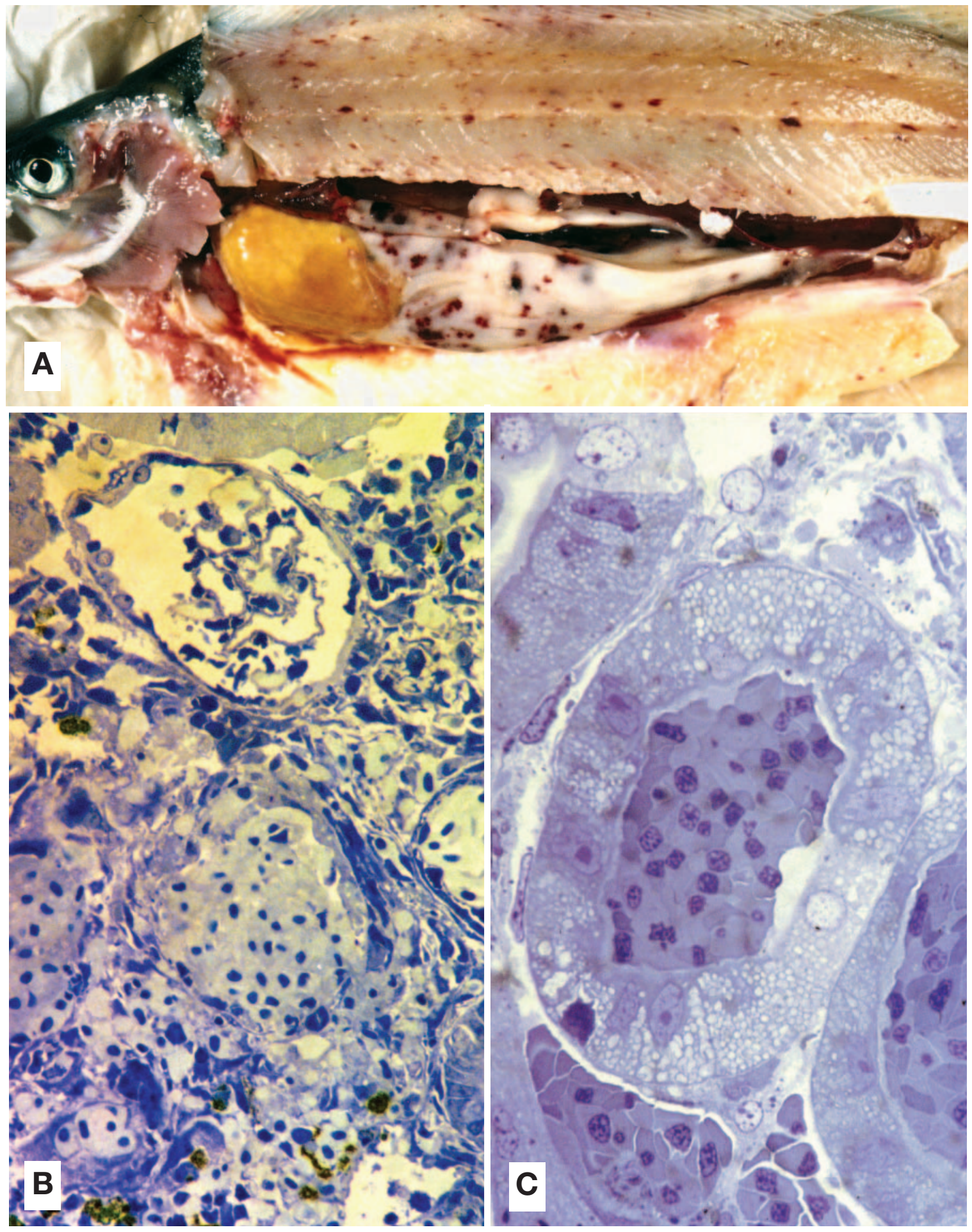

Fig. 1. Salmo salar. (A) Internal clinical signs of haemorrhagic smolt syndrome (HSS). (B,C) Sections through kidney of Atlantic salmon with HSS, showing tubular and haematopoetic necrosis, necrosis of the glomeruli, and renal tubules filled with erythrocytes

had pale gills, some had petechia on the belly, dermal pockets of oedema, haemorrhages at the fin bases and on the inside of the operculum, and bleeding from inflamed vents. Internal haemorrhage was accompa- nied by some ascitic fluid, petechia and ecchymosis on the viscera and somatic muscle (Fig. 1A). The liver was bright yellow and sometimes with ecchymosis. The spleen was dark and swollen. There were multi-focal 
haemorrhages in the swim-bladder and posterior gut. The gut contained a yellow material. The pericardial cavity was filled with fluid and petechiation was evident on the heart.

The haematocrit ratio of the fish examined was $<10 \%$ and, in some cases, as low as $2 \%$. Blood-smears revealed mostly normal erythrocytes, but the frequency of immature erythrocytes and 'smudge' cells was fairly high. There seemed to be a higher percentage of leukocytes compared to blood-smears from normal salmon. However, a quantification of the percentage of leukocytes was not carried out.

Histological examination revealed haemorrhage and necrosis in most tissues. The gills of some of the fish displayed epithelial cell hypertrophy, and some cells showed signs of necrosis. Salmon from 1 farm (Sogn og Fjordane) displayed an extreme increase of hypertrophied chloride cells, i.e. the secondary lamellae were completely dominated by these cells. The kidneys had haemorrhages in the glomeruli and multifocal necrosis of the haematopoetic tisssue (Fig. 1B,C). Large portions of the renal tubules were filled with erythrocytes and the nucleus of the tubular epithelial cells had moved to the apical part of the cells. The tubular epithelial cells showed clear signs of necrosis. There were areas with multi-focal haemorrhages and necrosis in the liver (Fig. 2A). The liver cells were strongly vacuolated (multiple small vacuoles) and the nuclei were karyorectic with what seemed to be double/triple nucleoli (Fig. 2B,C). TEM revealed that these inclusions consisted of amorphic material, possibly lipid. The spleen showed widespread necrosis, degeneration and erythrophagocytosis. Changes in the heart were characterised by necrosis, loss of striation, vacuolisation, and haemorrhage of the ventricular myocardium, especially at the junction between the compact and the spongy layers of the ventricle or in the compact layer only (Fig. 2D,E). There were few or no changes in the epi-, endo- and myocardium of the atrium. However, invasion of leukocytes was observed in the myocardium of some of the atria. The skeletal muscles had focal haemorrhages throughout the length of the fish (Fig. 1A) and degeneration and loss of striation of myofibres close to the haemorrhages. There were also haemorrhages in the visceral fat and pancreatic tissue, but there was no clear loss of pancreatic tissue. There was some sloughing of the hind gut epithelium and some haemorrhages in the muscular layers of the gut, but few changes were observed in the pyloric caeca.

There was no microscopic evidence of any parasites that could explain the disease. Similarly, no bacteria were isolated from the fish. TEM revealed 2 different virus-like particles in tissues of all salmon from the 3 farms studied (cf. Table 1). The first of the virus-like particles, Type I, were found only intracellularly. The target cells were blood vessel endothelial cells, endocardial cells and granulocytes in the kidney (Fig. 3A). Type I particles, varying from 50 to $60 \mathrm{~nm}$ in diameter, were located in cytoplasmic vacuoles filled with amorphous material (Fig. 3B,C). A unit membrane did not surround these particles, i.e. they were naked. Type II particles were about $50 \mathrm{~nm}$ in diameter, membrane-bound, and had an electron-dense core (Fig. 4) about $20 \mathrm{~nm}$ in diameter. Type II particles were seen budding from the surface of heart myofibres, endothelial cells lining blood vessels, endocardial cells and unidentified cells in the kidney (Figs. $5 \& 6$ ). These particles were also seen budding into the space between the 2 unit membranes surrounding the cell nucleus (Fig. 6C). Uptake of single particles into these cells was also observed (Fig. 7). Vacuoles containing these virus-like particles were observed in endothelial cells lining the blood vessels and in unidentified cells in the kidney. Heart myofibres associated with these virus-like particles seemed to have an enlarged nucleus and, in a few cases, nuclear inclusions.

All cell cultures (ASK cells, CHSE-214 and EPC) were negative, but some changes were observed in ASK-cells $4 \mathrm{~d}$ after challenge. However, these cells recovered and the cytopathic effect was not repeated when the supernatant was transferred to a new cell culture flask.

No fishes (salmon and rainbow trout) died during the challenge experiment and no clinical signs of disease were observed. Sections for light and electron microscopy were not made from any tissues from challenged fishes.

None of the fishes (Rogaland, 8 April) examined by immunofluorescence were found positive for ISAV or IPNV.

When screened for ISAV, IHNV, VHSV, SDV and SPDV with RT-PCR, fish from all farms were negative with the exception of 1 out-take of material from Rogaland (16 April). This material was positive for SPDV/SDV (Primers PDF1/PDR1). The PCR product was sequenced (Accession No. AY069950) and aligned against sequences from SPDV (AJ012631) and SDV (AJ238578). The similarity of the nucleotide sequence product was $95 \%$ for SPDV and $90.4 \%$ for SDV, while the similarity between SPDV and SDV in this partial sequence area was $90.4 \%$.

\section{DISCUSSION}

The possible causes (infectious, feed-related, toxic, traumatic, hypersensitive, hormonal, autoimmune or genetic aetiologies) of haemorrhagic smolt syndrome 


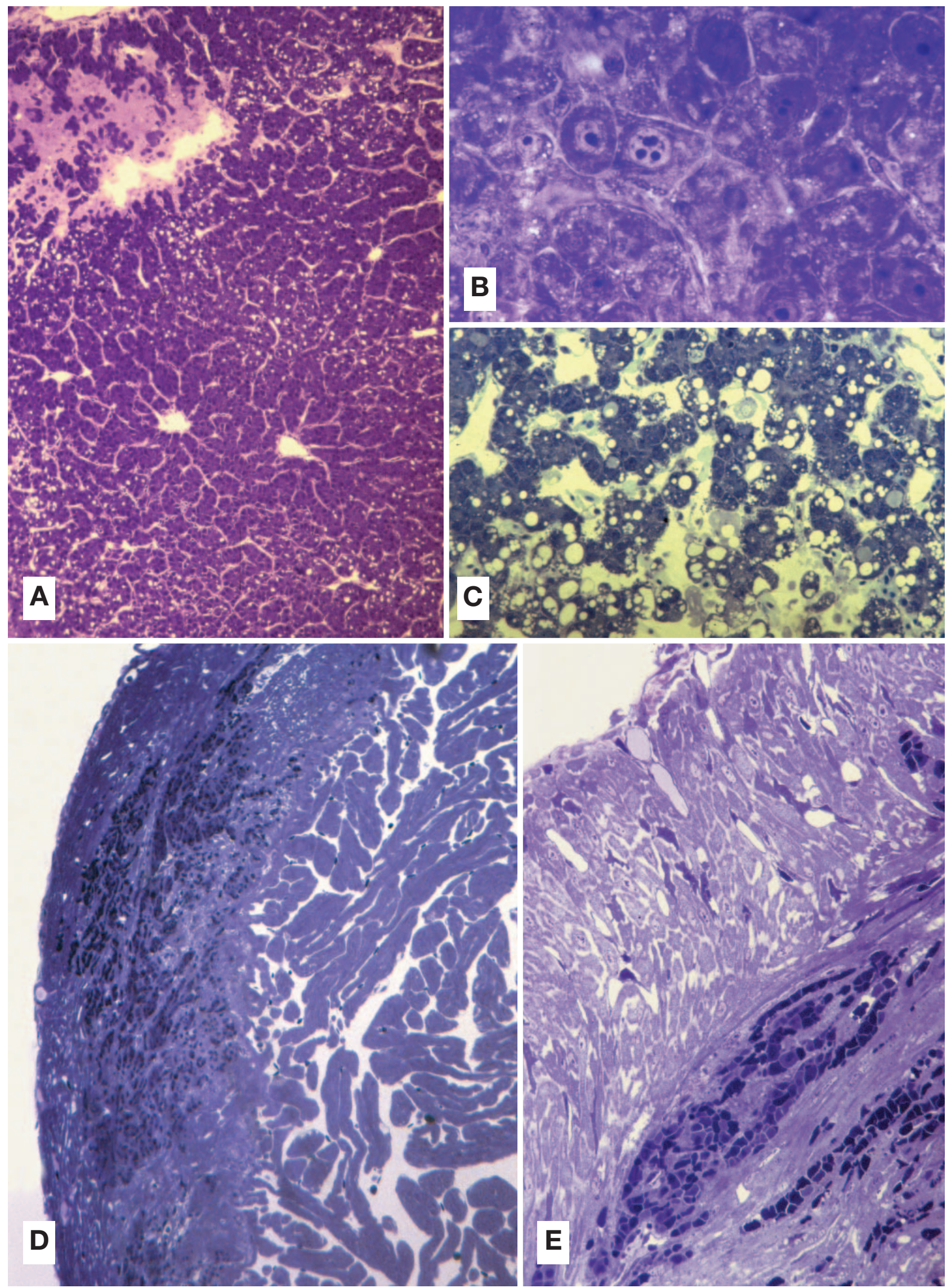


Fig. 2. Salmo salar. (A) Necrosis in the liver. (B) Nuclear inclusions in liver cells. (C) Degenerated and vacuolated liver cells. $(\mathrm{D}, \mathrm{E})$ Haemorrhage and necrosis in the compact layer of the heart ventricle close to the spongy layer
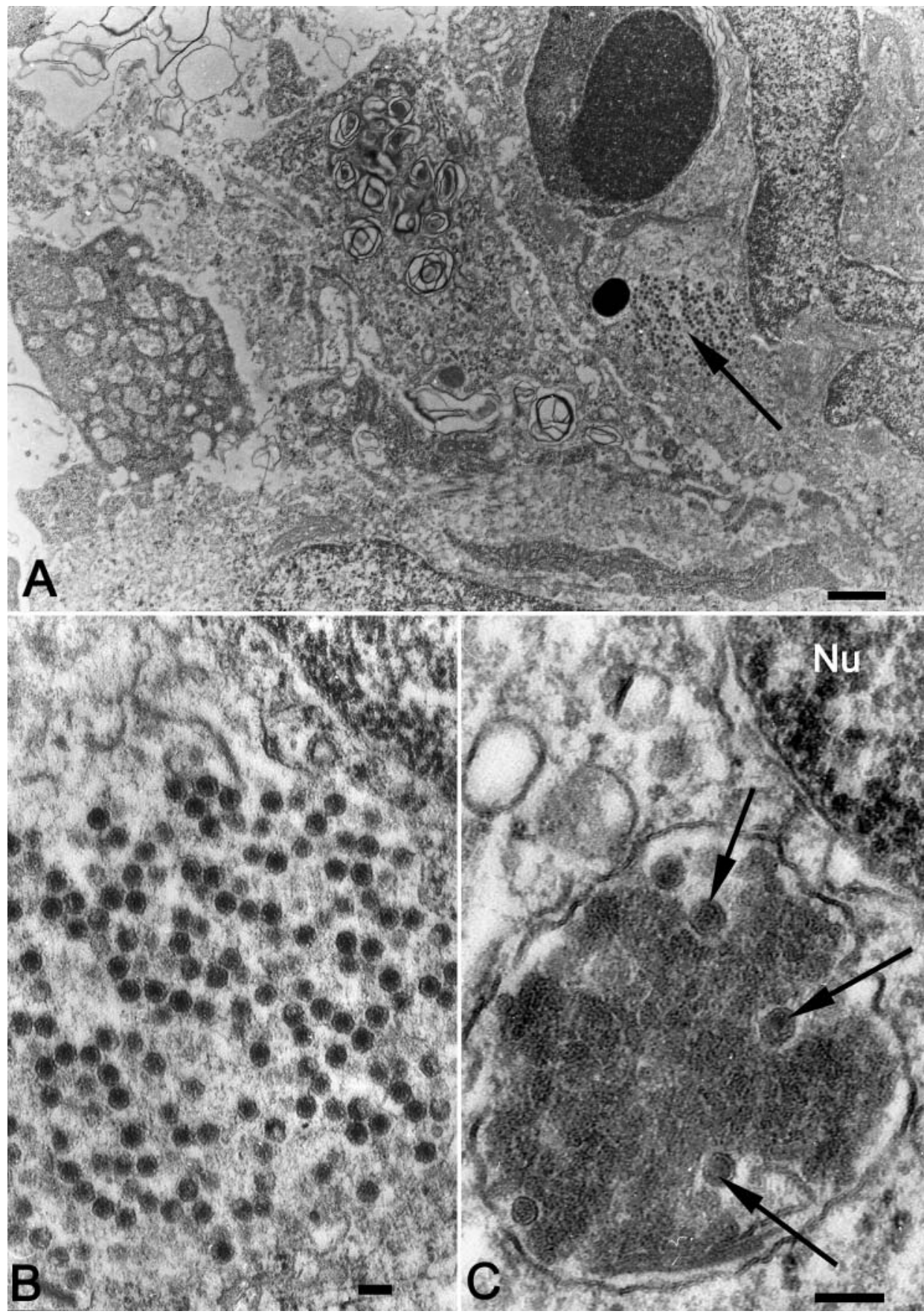

Fig. 3. Salmo salar. (A) Virus-like particles, Type I (arrow), in kidney from salmon suffering from HSS (scale bar $=1.0 \mu$ m). (B) Magnification of the virus-like particles in (A); particles are without a membrane coat and are located in cytoplasmic vacuoles (scale bar $=0.1 \mu \mathrm{m})$. $(\mathrm{C})$ Type 1 particles (arrows) in a vacuole in cytoplasm of an endothelial blood vessel cell from compact layer of the heart; particles are surrounded by electron-dense amorphous material (scale bar $=0.1 \mu \mathrm{m}$ ) 

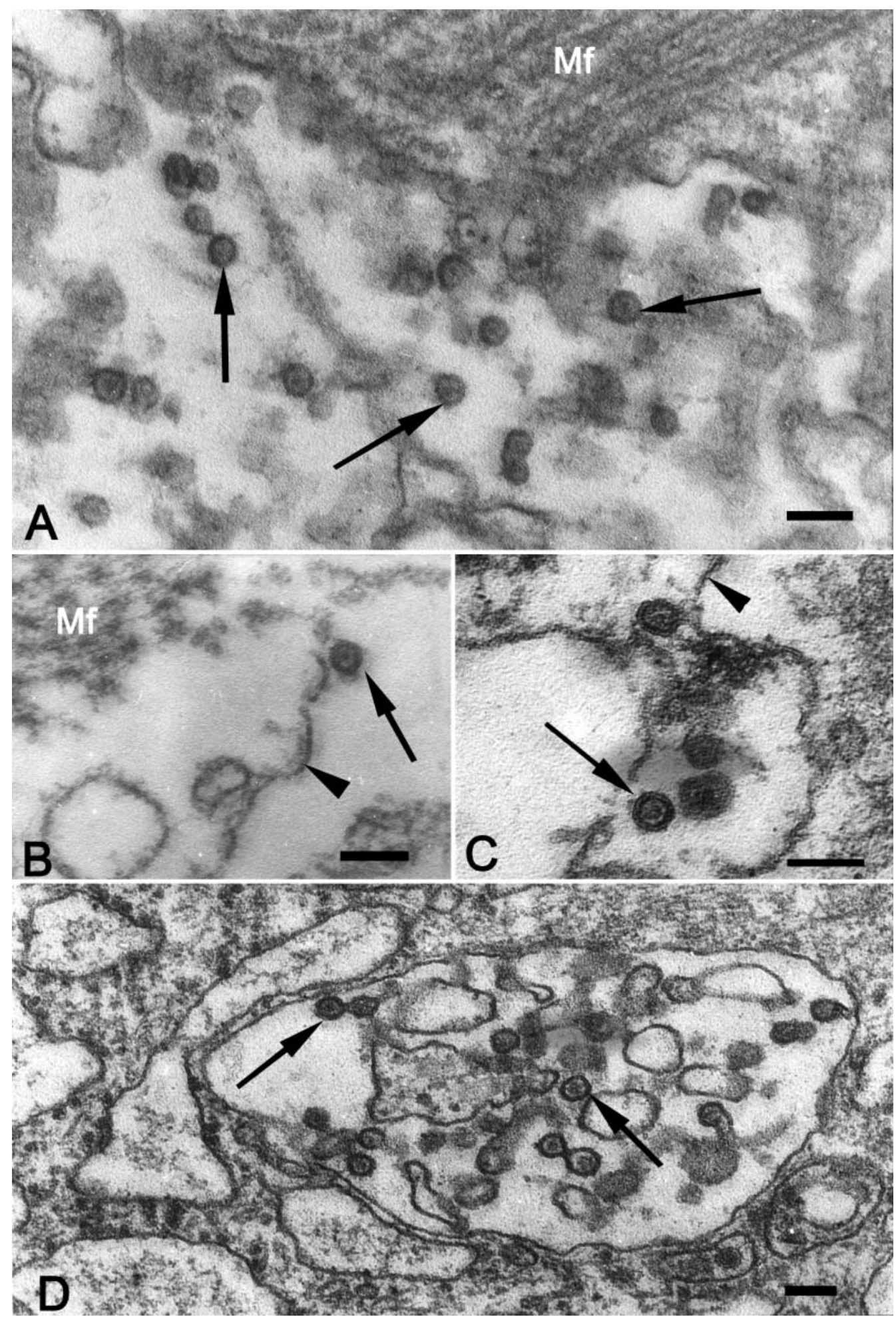

Fig. 4. Salmo salar. (A) Virus-like particles, Type II (arrows), in heart of salmon from western Norway suffering from HSS. (B) Same type of particle (arrow) in heart (ventricle) of salmon with HSS collected from northern Norway; cell membrane of the ventricular heart myofibre (arrowhead). (C) High magnification of Type II particles (arrow) showing the central core surrounded by a unit membrane; note that the particle unit membrane appears thicker than the cell unit membrane (arrowhead). (D) Type II particles (arrows) within a vascular endothelial cell vacuole in the kidney of a salmon suffering from HSS; these intra-vacuolar Type II particles are of the same size and morphology as those from the heart tissue. Mf $=$ myofilaments in a ventricular heart myofibre. (All scale bars $=0.1 \mu \mathrm{m}$ ) 


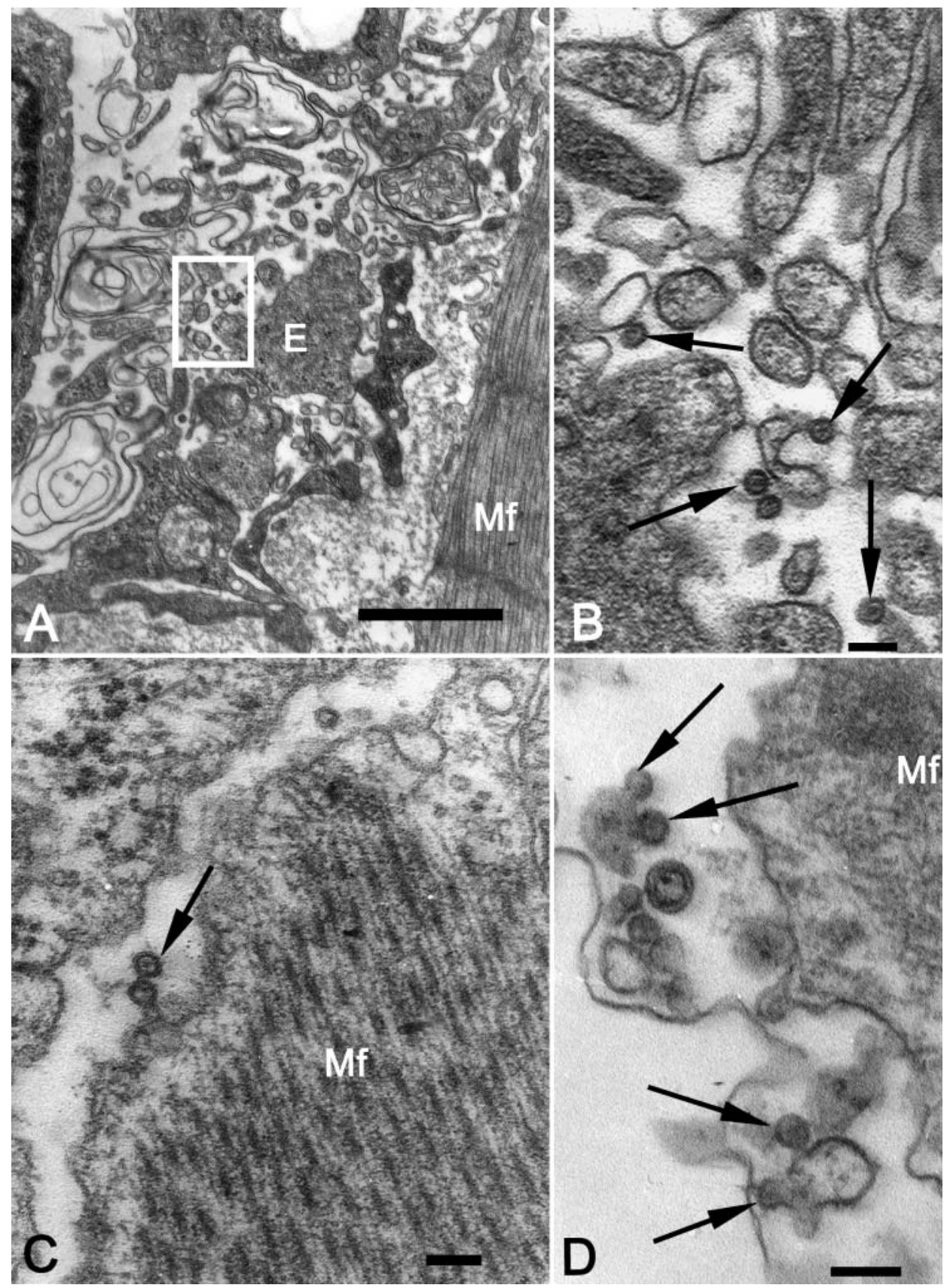

Fig. 5. Salmo salar. (A) Type II particles associated with endocardial cells in the ventricle of salmon suffering from HSS; E = Endocardial cell. $\mathrm{Mf}=$ myofilaments in a ventricular myofibre. Boxed area is magnified in (B) (scale bar = 1.0 $\mu \mathrm{m})$. (B) Magnification of boxed area in (A) showing Type II particles (arrows) in the heart ventricular lumen (scale bar $=0.1 \mu \mathrm{m}$ ). (C,D). Budding of Type II particles (arrows) from ventricular heart myofibres (scale bars $=1 \mu \mathrm{m}$ ). $\mathrm{E}=$ endocardial cell; Mf $=$ myofibrils in ventricular heart myofibre

(HSS) Salmo salar have been discussed at length by Rodger \& Richards (1998). Based on circumstantial evidence of HSS association with smoltification (the pathology being indicative of increased endothelial tissue permeability or degeneration and the obvious failure of blood to clot normally), these authors con- cluded that the possible cause of HSS is either a feedrelated deficiency or a genetically induced disorder that becomes clinically significant of the smoltstage. They recommended that feed and tissue samples should be screened for Vitamins $\mathrm{C}$ and K. However, the severity of the disease, with extremely low haema- 


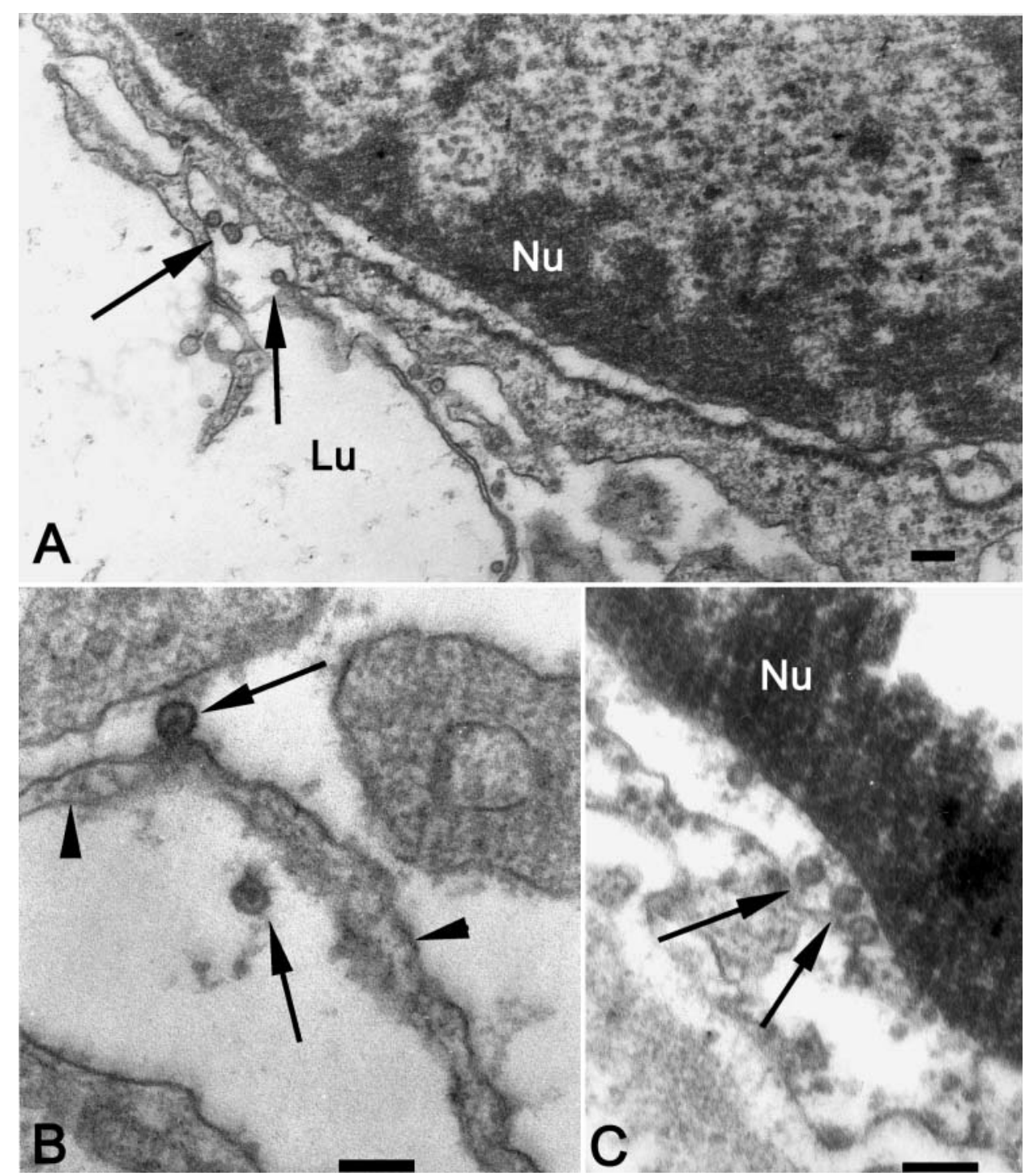

Fig. 6. Salmo salar. (A) Budding of Type II particles (arrows) from an endothelial cell of blood vessel in the kidney of salmon suffering from HSS. (B) Budding of Type II particles (arrows) from protrusion (arrowheads) of an unidentified cell in the kidney. (C) Type II particles in the nuclear envelope of an endocardial cell in the heart ventricle; note that the particles are located between the 2 unit membranes; these particles have been observed budding from the outer unit membrane surrounding the nucleus of heart myofibres and endocardial cells. $\mathrm{Nu}=$ cell nucleus; $\mathrm{Lu}=$ blood vessel lumen. (All scale bars $=0.1 \mu \mathrm{m}$ )

tocrit values, and necrosis of cells and tissues in most organs, may also point towards an infectious aetiology (to some extent similar to rhabdovirus infections in fishes, cf. Wolf 1988). In addition, observations in salmon farms indicate that this disease also occurs in sea water (C. Koren pers. obs.) and may be transmitted from one net pen to another. In sea water, the disease has a more sub-clinical character, and up to $90 \%$ of salmon may be affected. The working hypothesis of this study of HSS in Norwegian smolt production has been that the disease is caused by an infectious agent, most likely a virus.
Bacteria and parasites (proliferative kidney disease, PKD) have been associated with severe anaemia, but such parasites and bacteria can be excluded as a possible cause of HSS. It is known that ectoparasites (Gyrodactylus spp. and Ichthyobodo spp.) and bacteria causing skin erosions and osmoregulatory failure may cause an anaemic condition, but in the present study no such agents were found in any quantity that could explain the clinical effects of HSS. No bacteria that can explain the disease were cultured from fishes with HSS, and histological study and TEM of tissues and cells did not reveal any bacteria or parasites. These 


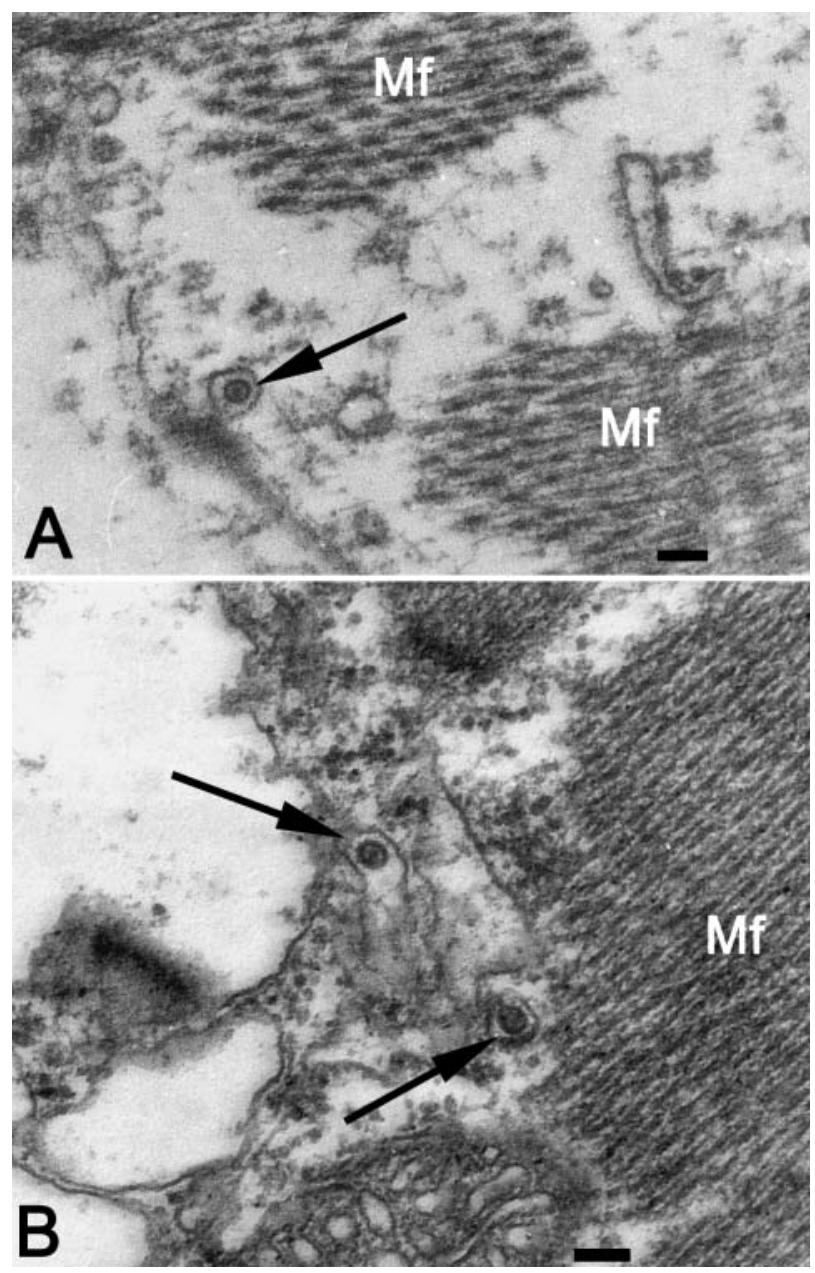

Fig. 7. Salmo salar. (A,B) Endocytosis of Type II particles (arrows) into ventricular heart myofibres. $\mathrm{Mf}=$ myofibrils in a ventricular heart myofibre. (Scale bars $=0.1 \mu \mathrm{m})$

findings are in accordance with those of Rodger \& Richards (1998).

Severe anaemia is associated with a number of infectious, predominantly viral, diseases in fishes, and in Norwegian aquaculture these are ISA, IPN, SPD and VHS. VHS has been registered a few times only in Norwegian aquaculture, and is mostly associated with rainbow trout farming. Other severe rhabdovirus infections, such as IHNV and SCV, have not been found in Norway. However, of the infectious agents considered, the most likely candidate would be an endotheliotropic virus such as the ISA virus or several rhabdoviruses. It was not possible to culture any rhabdoviruses, and the RT-PCR protocol for IHNV and VHSV gave negative results. This does not, however, exclude the possibility that an unknown rhabdovirus with low virulence may be the cause of HSS. So far, it has not been possible to find any rhabdovirus-like particles (TEM) in tissues from salmon with HSS.
ISA is a disease with a fairly long history in Norway and some of the gross pathological signs of HSS, such as severe anaemia (haematocrit values as low as $1 \%$ ) and erythro-phagocytosis, are similar to those of ISA (Thorud \& Djupvik 1988, Evensen et al. 1991). Still, the majority of the clinical signs of HSS and its histopathology are not consistent with ISA. In addition, the low mortality $(<0.5 \%)$ accompanying $\mathrm{HSS}$ is not usual during ISA outbreaks, when mortalities between 50 and $80 \%$ are likely to occur. However, these signs are only indicative of ISA and the disease can only be safely diagnosed by IFAT, cell-culture plus IFAT, or by RT-PCR. Most of these diagnostic tools have been used on salmon with HSS, and in addition homogenates from HSS fishes have been injected into salmon and rainbow trout, but the results have all been negative for ISA or the presence of the ISA viral genome. These results are also in accordance with the transmission trial performed by Rodger \& Richards (1998), who, however, carried out transmission at $4^{\circ} \mathrm{C}$ and waited only $4 \mathrm{wk}$ (28 d) before their fish were sampled (killed). In a study by Thorud \& Djupvik (1988), mortality did not start until 35 d (5 wk) after challenge of salmon with ISAinfected material at $3^{\circ} \mathrm{C}$. Hence, the lack of mortality in the trial by Rodger \& Richards (1998) could be the result of low water temperature and slow development of ISA. The transmission trials in the present study were performed at $12{ }^{\circ} \mathrm{C}$ and mortality was expected to occur between 15 and $20 \mathrm{~d}$ after challenge, but no mortality occurred during the experimental period of 9 mo. Based on these results (challenge, RT-PCR, cell culture, and IFAT), it should be safe to conclude that HSS is not caused by a strain of the ISA virus.

The smolt production sites in this study all had a history of IPN. Hence, fish from all the farms were considered positive for IPN virus (even though the IFAT on the material from Rogaland [8 April] was IPNVnegative) and 1 farm had a positive diagnostic for IPNV (diagnosed by the Norwegian National Veterinary Service). Before culturing, antibodies neutralising the IPN virus were added to all inoculates. The IPN virus (or aquatic birnaviruses) is very common in fishes in fresh and salt water in Norway and in aquaculture world-wide (cf. Essbauer \& Ahne 2001). The aquatic birnaviruses share similarities in morphology and biochemical/biophysical properties. The IPN virus is nonenveloped, single-shelled, with icosahedral morphology, and measures $60 \mathrm{~nm}$ in diameter (Essbauer \& Ahne 2001). Although the Type I particles found in salmon suffering from HSS were closer to $50 \mathrm{~nm}$ than $60 \mathrm{~nm}$ in diameter in the present study, they are most likely IPNV virions. There have been reports of the IPN virus varying in size from 50 to $75 \mathrm{~nm}$ (cf. Wolf 1988). However, there are no indications in the literature on challenge experiments and field material that IPNV 
may cause clinical signs such as those observed in salmon with HSS. The presence of IPN virus-like particles in the HSS salmon studied herein could be an accidental finding or a secondary invasion. Another possibility is that IPNV in combination with a not yet identified virus is the cause of HSS in salmon.

Lesions often associated with SPDV (and that are to some degree similar in HSS) are multifocal cardiomyofibre necrosis with loss of striation in the compact layer of the ventricle and myopathic changes in the somatic muscles. However, the changes in the heart and somatic muscles of salmon with SPDV seem to be much more severe (including subendocardial cell proliferation, increased cellularity at the junction of the stratum compactum and stratum spongiosum of the ventricle, degeneration of somatic myofibres with centralisation of nuclei, and massive infiltration of inflammatory cells; McLoughlin et al. 1995, McLoughlin 1997) than in fish with HSS. In addition, loss of most of the pancreatic tissue with acinar necrosis is commonly observed in fish suffering from SPDV, while most of the pancreatic tissue in salmon with HSS is still morphologically intact, even when characterised by necrosis and haemorrhages. A newly developed RT-PCR for diagnosting SPDV gave no positive results, suggesting that this virus is not involved. However, the primer set developed for recognising both SPDV and SDV revealed 1 positive sample (16 April) from the outbreak of HSS in Rogaland. The other (earlier) samples from the same farm and from other farms screened by RT-PCR were negative. Still, a possible presence of SPDV/SDV cannot be excluded, since this virus may have been 'lost' from the tissues at the time of sampling from moribund fish. In addition, these viruses are not easy to culture even when present in tissues.

The Type II virus-like particles (TEM) found in tissues (heart and kidney) from Atlantic salmon suffering from HSS had the same size, morphology and target cells at all 3 localities (Rogaland, Sogn og Fjordane and Troms). Replication of this virus seems to involve budding from the cell surface and receptor-mediated endocytosis. In addition, budding into Golgi complexes also seems to occur, since a number of these particles were found within cytoplasmic vacuoles. Among the known viruses isolated from vertebrates there are just a few families that contain enveloped viruses of the correct morphology and size, the RNA virus families Flaviviridae and Togaviridae and the DNA family Hepadnaviridae. Among these 3 families, only togaviruses replicate by receptor-mediated endocytosis and budding from the cell surface. The general morphological characteristics of the toga- and flaviviruses are fairly constant, and the virions are spherical and enveloped with a diameter of 45 to $70 \mathrm{~nm}$ and a nucleocapsid of 25 to $35 \mathrm{~nm}$ diameter (Dalton \& Haguenau
1973, Fields 1996). The flaviviruses are 45 to $60 \mathrm{~nm}$ and the togaviruses 60 to $70 \mathrm{~nm}$ in diameter.

Alphatogaviruses are known to have a wide host range and may replicate in many different cell types. Among the known fish viruses, both SPDV and SDV are believed to be alphatogaviruses (Nelson et al. 1995, Weston et al. 1999, Villoing et al. 2000a,b, Welsh et al. 2000). Based on their genome sequence, these 2 viruses seem to be closely related (Weston et al. 1999, Villoing et al. 2000a). The size of the SPDV, $65.5( \pm 4.3) \mathrm{nm}$, has been given by Nelson et al. (1995), who measured the SPDV particles on negative-stained preparations. Unfortunately, the micrograph presented in their publication provides little information about the morphology of the virus. However, the SPDV was sensitive to chloroform, which indicates that it is an enveloped virus (Nelson et al. 1995). It is not possible to compare the virus-like particles described in the present paper with those illustrated by Nelson et al. (1995). However, the difference in size could be due to different methods of preparation for electron microscopy, i.e. negative staining versus staining for sectioning and traditional transmission electron microscopy. The virus size in the present paper is closer to that given for the SPDV (50 to $60 \mathrm{~nm}$ ) by LopezDoriga et al. (2001), who based their measurements on the same method as that used in our study. The SDV is 55 to $60 \mathrm{~nm}$ in size according to Castric et al. (1997) and Villoing et al. (2000a), which is also close to the size of the HSS virus-like particles (HSSV). The traditional TEMs of the SDV presented by Villoing et al. (2000a: one of the TEMs on p. 175, Fig. 2, bottom figure) show particles that are morphologically identical to HSSV particles. However, the top TEM in the same figure shows morphologically different particles, i.e. particles with an electron-dense core that fills the whole volume enclosed by the unit membrane. Among the known togaviruses, the rubella virus can be distinguished from the other viruses in this family by a distinctive electron-lucent zone between the virus core and the envelope (Fields 1996). This means that the HSSV particles (and one of the particles presented by Villoing et al. 2000a) are morphologically more similar to the rubella virus than to members of the alphaviruses. Rubella is the only member of the genus Rubivirus. The size of the HSS virus-like particles is closer to that of flaviviruses (40 to $60 \mathrm{~nm}$ ), but their mode of replication suggests that the HSSV particles do not belong to this group.

The present study has not shown that the HSS viruslike particle (Type II) described is a virus and the causative agent of HSS. However, the disease morphology and location (budding from cell surfaces) give a strong indication that it may be a virus. The presence of a high number of these particles in Atlantic salmon suffering from HSS at 3 different localities along the Norwegian coast suggests a close association between 
the disease and this possible agent. The phylogenetic relationship of this possible agent with other viruses is at present unknown, although the disease morphology is similar to that produced by togaviruses. Lack of positive results with the RT-PCR using primers against SPDV and SDV could, however, be due to slight differences in genome sequences between these 2 and HSSV, indicating a different isolate within this group of viruses. The existence of several different isolates in this group of viruses is also supported by the positive RT-PCR (PDF1/PDR1) from the Rogaland material (16 April), in which the sequence identity between SPDV, SDV and the isolate from HSS-salmon, in a short (197 bp) region, ranged from 90.4 to $95 \%$. Hence, the HSSV particle found in this study could belong to the same group of viruses as SPDV and SDV, or it could just be an isolate of SPDV. Lack of positive RT-PCR could have been due to low sensitivity of the primer set used. However, the pathology and the indication of apparent differences in the genome sequence of HSSV suggest that it is sufficiently different to be separated from the 2 other viruses.

Based on clinical signs, histopathology and TEM, HSS cannot be confused with other salmon diseases with unclear aetiologies such as cardiomyopathy syndrome (Ferguson et al. 1990, Nylund 2001) or viral diseases such as SD and SPD. However, it should be pointed out that clinical signs and histopathology are not very safe criteria for diagnosis. Further studies will have to be carried out to make a valid separation between HSS and other salmon diseases. Circumstantial evidence, such as the presence of HSS in sea water (sub-clinical), possible transmission between net pens and the virus-like particles revealed by TEM, supports the hypothesis that the disease has a viral aetiology. Still, until successful transmission trials have been performed, it cannot be excluded that the disease may be related to factors other than viruses. Much work remains to be done before a valid aetiology can be determined, but meanwhile, HSS should be treated as an infectious disease to prevent the spread of a possible infectious agent.

\section{LITERATURE CITED}

Castric J, Baudin Laurencin F, Bremont M, Jeffroy J, Le Ven A, Bearzotti M (1997) Isolation of the virus responsible for sleeping disease in experimentally infected rainbow trout (Oncorhynchus mykiss). Bull Eur Assoc Fish Pathol 17: 27-30

Dalton AJ, Haguenau F (1973) Ultrastructure of animal viruses and bacteriophages: an atlas. Academic Press, London

Devold M, Krossøy B, Aspehaug V, Nylund A (2000) Use of RT-PCR for diagnosis of infectious salmon anaemia virus (ISAV) in carrier sea trout Salmo trutta after experimental infection. Dis Aquat Org 40:9-18

Essbauer S, Ahne W (2001) Viruses of lower vertebrates. J Vet Med Ser B 48:403-475

Editorial responsibility: Jo-Ann Leong,

Kaneohe, Hawaii, USA
Evensen Ø, Thorud KE, Olsen YA (1991) A morphological study of the gross and light microscopic lesions of infectious anaemia in Atlantic salmon (Salmo salar). Res Vet Sci $51: 215-222$

Falk K, Dannevig BH (1995) Demonstration of infectious salmon anaemia (ISA) viral antigens in cell cultures and tissue sections. Vet Res 26:499-504

Ferguson HW, Poppe T, Speare DJ (1990) Cardiomyopathy in farmed Norwegian salmon. Dis Aquat Org 8:225-231

Fields BN (1996) Virology. Lippincott-Raven, Philadelphia, PA

Frost P, Børsheim K, Endresen C (1998) Analysis of the antibody response in Atlantic salmon against recombinant VP2 of infectious pancreatic necrosis virus (IPNV). Fish Shellfish Immunol 8:447-456

Lopez-Doriga MV, Smail DA, Smith RJ, Domenech A, Castric J, Smith PD, Ellis AE (2001) Isolation of salmon pancreas disease virus (SPDV) in cell culture and its ability to protect against infection by the 'wild-type' agent. Fish Shellfish Immunol 11:505-522

McLoughlin MF (1997) The differential diagnosis of the major pancreatic disorders of salmonids, a diagnostic challenge. Bull Eur Assoc Fish Pathol 17:205-208

McLoughlin MF, Nelson RT, McCormick JI, Rowley H (1995) Pathology of experimental pancreas disease in fresh water Atlantic salmon (Salmo salar) parr. J Aquat Anim Health $7: 104-110$

Miller TA, Rapp J, Wastlhuber U, Hoffmann RW, Enzmann PJ (1998) Rapid and sensitive reverse transcriptasepolymerase chain reaction based detection and differential diagnosis of fish pathogenic rhabdoviruses in organ samples and cultured cells. Dis Aquat Org 34:13-20

Nelson RT, McLoughlin MF, Rowley HM, Platten MA, McCormick JI (1995) Isolation of a toga-like virus from farmed Atlantic salmon Salmo salar with pancreas disease. Dis Aquat Org 22:25-32

Nylund A (2001) Hjerteprekk, kardiomyopatisyndrome (CMS). Fiskehelse 1:29-37 (in Norwegian)

Nylund A, Hovland T, Watanabe K, Endresen C (1995) Presence of infectious salmon anaemia virus (ISAV) in tissues of Atlantic salmon, Salmo salar L., collected during three separate outbreaks of the disease. J Fish Dis 18:135-145

Rodger HD, Richards RH (1998) Haemorrhagic smolt syndrome: a severe anaemic condition in farmed salmon in Scotland. Vet Rec 142:538-541

Szilvay AM (1988) Produksjon og karakterisering av monoklonale antistoffer til påvisning av IPN-virus i celler og vev. Cand. Scient. thesis, Center of Biotechnology, University of Bergen (in Norwegian)

Thorud K, Djupvik HO (1988) Infectious anaemia in Atlantic salmon (Salmo salar). Bull Eur Assoc Fish Pathol 8:109-111

Villoing S, Bearzotti M, Chilmonczyk S, Castric J, Bremont M (2000a) Rainbow trout sleeping disease virus is an atypical alphavirus. J Virol 74:173-183

Villoing S, Castric J, Jeffroy J, Le Ven A, Thiery R, Bremont M (2000b) An RT-PCR-based method for the diagnosis of the sleeping disease virus in experimentally and naturally infected salmonids. Dis Aquat Org 40:19-27

Welsh M, Weston J, Borghmans BJ, Mackie D, Rowley H, Nelson R, McLoughlin M, Todd D (2000) Biochemical characterization of salmon pancreas disease virus. J Gen Virol 81:813-820

Weston JH, Welsh MD, McLoughlin MF, Todd D (1999) Salmon pancreas disease virus, an alphavirus infecting farmed Atlantic salmon, Salmo salar L. Virology 256: 188-195

Wolf K (1988) Fish viruses and fish viral diseases. Cornell University Press, Ithaca, NY

Submitted: December 14, 2001; Accepted: September 16, 2002 Proofs received from author(s): February 10, 2003 